\title{
Efek Penempatan dan Kepuasan Kerja terhadap Produktivitas: Studi Kasus pada PT. Rezki Laifasto
}

Keywords: work placement, satisfaction, productivity

\begin{abstract}
Abstrak:
Penelitian ini bertujuan untuk menguji pengaruh penempatan dan kepuasan kerja karyawan terhadap produktivitas dalam berkinerja. Penelitian ini adalah studi kasus yang dilakukan di PT. Reski Laifasto Cabang Makassar. Sampel penelitian sebanyak 71 karyawan. Metode penelitian kuantitatif digunakan dalam penelitian ini melalui analisis regresi berganda. Hasil penelitian mengungkapkan bahwa penempatan dan kepuasan kerja menyediakan efek positif terhadap produktivitas. Hasil ini mengindikasikan bahwa tingkat produktivitas kerja karyawan pada PT. Reski Laifasto Cabang Makassar ditentukan oleh penempatan kerja yang baik dan efek kepuasan kerja karyawan.
\end{abstract}

Kata kunci: penempatan kerja, kepuasan, produktivitas

\section{Pendahuluan}

Salah satu indikator ketercapaian tujuan perusahaan yang telah ditetapkan adalah peran aktif karyawan sebagai komponen sistem perusahaan.Tujuan perusahaan akan tercapai ketika karyawan mampu untuk mengembangkan keahlian dan kompetensinya serta menunjukkan sikap yang positif oleh karena itu perusahaan membutuhkan karyawan yang berkualitas dan berkuantitas.Karyawan yang berkualitas dan berkuantitas diperlukan oleh perusahaan agar produktivitas kerja karyawan dapat meningkat yang akan berdampak terhadap perkembangan perusahaan. Kualitas dan kuantitas karyawan akan terwujud apabila perusahaan mampu untuk mengelola karyawan secara efektif dan efesien (Handoko, 2011).

Karyawan harus ditempatkan pada suatu posisi yang sesuai dengan keahlian dan keterampilannya agar dalam bekerja mereka mampu untuk mengelola pengetahuan, skill dan keterampilannya dalam menyelesaikan pekerjaan (Fandi, 2016). Perusahaan memiliki target terhadap penyelesaian waktu kerja karyawan oleh karena itu karyawan dituntut untuk mampu menyelesaikan pekerjaan sesuai dengan waktu yang telah ditentukan. Dalam mencapai target kerja bagian HRD (Human Resourdh 
Development) dan pimpinan perusahaan harus mampu untuk menempatkan karyawan pada posisi yang tepat karena penempatan karyawan pada posisi yang tepat merupakan suatu hal yang erat kaitannya dengan pencapaian produktivitas kerja karyawan dalam memberikan manfaat yang besar bagi perusahaan. Seperti halnya yang dikemukakan oleh Mathis \& Jackson (2019) bahwa "Penempatan adalahmenempatkan posisi seseorang ke posisipekerjaan yang tepat, seberapa baik seorangkaryawan cocok dengan pekerjaanya akanmempengaruhi jumlah dan kualitas pekerjaan."

Penempatan karyawan yang tepat bukan hanya keinginan karyawan semata akan tetapi pihak perusahaan juga mempunyai keinginan untuk menempatkan karyawan pada posisi yang sesuai dengan bidang keahlian dan pengalamannya. Akan tetapi terkadang perusahaan tidak mampu untuk menempatkan karyawan sesuai dengan prinsip "the right man in the right place", sebab terkadang ada kesalahan dalam menilai dan memilih karyawan untuk menempati suatu posisi yang kosong dalam perusahaan dan adanya kendala pemberian "acselary" yang tinggi bagi karyawan yang betulbetul mempunyai kemampuan dan pengalaman serta prestasi kerja yang bagus, apabila orang yang tepat ditempatkan pada posisi yang tepat itu.

Mangkunegara (2011) menyatakan bahwa "ketidaktepatan menilai dan memilih karyawan untuk jabatan-jabatan tertentu seringkali karena lemahnya mutu instrumen dan prosedur yang dipakai. Dengan demikian, fungsi penempatan karyawan baru tidak taat asas dengan kemampulabaan perusahaan". Berdasarkan pendapat ini dapat dinyatakan bahwa ketika perusahaan tidak mempunyai laba yang tinggi, maka mereka tidak mampu untuk memberikan gaji yang tinggi kepada karyawan yang mempunyai keahlian dan pengalaman yang bagus. Sehingga berdampak kepada penempatan karyawan yang hanya berdasarkan kemampuan tanggung jawab karyawan terhadap pekerjaan tersebut.

Penempatan yang sesuai dengan keinginan dan kebutuhan perusahaan dan karyawan akan berdampak pada kepuasan kerja karyawan dan perusahaan, sebab karyawan mampu untuk menyelesaikan pekerjaan sesuai dengan keinginan perusahaan. Namun, ketika hanya keinginan dan kebutuhan perusahaan yang ingin terpenuhi tanpa pihak perusahaan memenuhi kebutuhan dan keinginan karyawan maka akan berpengaruh terhadap produktivitas kerja karyawan. Sikap puas atau tidak puasnya karyawan dalam bekerja dapat ditinjau dari adanya inisiatif dan perngembangan kerja yang dilakukan oleh karyawan dalam bekerja. Hal ini dikarenakan, apabila karyawan merasa puas dengan pekerjaan, maka mereka akan membuat suatu perubahan dan perbaikan untuk lebih mengefktifkan dan mengefesiensikan pekerjaan.

Ada beberapa hal yang mampu untuk membantu meningkatkan kepuasan kerja (Luthans, 2012, 2002) yaitu (1) membuat pekerjaan menjadi menyenangkan; (2) memiliki gaji, benefit, dan kesempatan promosi yang adil, (3) menyesuaikan orang dengan pekerjaan yang sesuai dengan minat dan keahlian mereka; dan (4) mendesain pekerjaan agar menarik dan menyenangkan. Kepuasan kerja karyawan akan muncul ketika pihak perusahaan tetap memberikan suatu apresiasi dan mau menerima segala kritik dan keluhan karyawannya. Serta berusaha untuk mempertahankan karyawan dengan memberikan suatu variasi dan keleluasan kepada karyawan tetapi keleluasaan itu tidak terlepas dari aturan-aturan perusahaan. Pada intinya karyawan akan tetap bertahan dalam perusahaan ketika mereka mendapatkan kenyamanan dan keadilan dalam bekerja sehingga kenyamanan dan keadilan itu berdampak pada kepuasan kerja karyawan dan juga akan memberikan dampark positif terhadap perusahaan. Firana \& Abbas (2020) menyatakan bahwa mutu kinerja manajerial cenderung meningkat dengan mempertimbangkan dimensi keadilan.

Pada dasarnya karyawan akan menunjukkan produktivitas kerja yang maksimal apabila mereka mendapatkan feedback dari pihak perusahaan terlepas dari apakah feedback itu berupa reward atau punishment. Dalam memberikan feedback ini pihak perusahaan harus mampu untuk berlaku objektif kepada karyawan sehingga karyawan merasa dihargai hasil kerjanya karena tinggi rendahnya produktivitas kerja karyawan tidak hanya dipengaruhi oleh sikap karyawan itu sendiri tapi juga dipengaruhi oleh lingkungan kerja dan perusahaan(Sunyoto, 2013).

Karyawan yang telah menunjukkan produktivitas kerja yang maksimal dan sudah seharusnya mendapatkan promosi kenaikan jabatan namun karena ketidak objektifan supervisor dalam menilai akan berdampak pada ketidak puasan kerja karyawan dan akan terjadi ketidaksesuaian penempatan ulang. Hal inilah yang menyebabkan produktivitas kerja karyawan terkadang tidak maksimal karena ketidakmampuan pihak perusahaan dalam memilih orang yang tepat serta kondisi perusahaan yang 
tidak menunjang secara optimal. Sedarmayanti (2016) mengemukakan bahwa dalam mencapai produktivitas kerja maksimum, organisasi harus menjamin dipilihnya orang yang tepat, dengan pekerjaan yang tepat disertai kondisi yang memungkinkan mereka bekerja secara optimal.

Dengan demikian, penelitian ini bertujuan untuk menguji pengaruh penempatan kerja dan kepuasan karyawan PT. Rezki Laifasto terhadap produktivitas kerja.

\section{Kajian Literatur}

Produktif atau tidaknya karyawan dalam bekerja dapat dilihat dari faktor yang mendorong karyawan untuk mau bekerja dengan baik. Faktor pendorong internal dan eksternal merupakan hal yang mampu memberikan kontribusi dalam memperbaikin produktivitas kerja karyawan. Apabila produktivitas kerja karyawan dikaitkan dengan penempatan karyawan, maka teori higienis dari Herzberg dapat menjelaskan tentang situasi yang dapat mendorong keadaaan karyawan untuk mau bekerja dengan baik.

Herzberg (2009) mengungkapkan bahwa ada beberapa hal yang dapat mendorong karyawan dalam bekerja berdasarkan hasil penelitian yang dilakukan oleh herzberg, yaitu karyawan akan termotivasi untuk bekerja apabila karyawan merasakan tantangan dalam bekerja, adanya tanggung jawab yang diberikan kepada karyawan serta adanya pengakuan atau peluang jabatan yang lebih baik yang diberikan perusahaan apabila karyawan berprestasi. Teori higienis menjelaskan bahwa apabila karyawan ditempatkan pada jabatan yang sesuai dengan keterampilan dan keahliannya, maka hal itu merupakan suatu penghargaan terhadap prestasi yang telah diraih oleh karyawan sedangkan untuk karyawan baru kesesuaian jabatan yang diberikan dengan pengalaman dan pendidikannya merupakan suatu pengakuan terhadap kemampuan karyawan. Herzberg dalam memotivasi karyawan lebih utama menyentuh kepada kebutuhan tingkat tinggi karyawan yang langsung mengarah kepada penghargaan yang akan didapatkan oleh karyawan. Teori herzberg mengindikasikan bahwa akan ada pengaruh yang terjadi antara penempatan karyawan dengan produktivitas kerja karyawan karena karyawan yang produktif adalah karyawan yang menyenangi pekerjaan dan tidak monotonnya pekerjaan yang dihadapi sehingga karyawan akan menunjukkan kreativitas mereka dalam menyelesaikan pekerjaan.

Tercapainya tujuan perusahaan tergantung pada cara manajemen sumber daya manusia atau HRD perusahaan menempatkan karyawannya pada posisi yang sesuai dengan keahlian, minat dan keterampilan karyawannya. Kualitas dan kuantitas dari karyawan merupakan salah satu faktor penentu dari tercapainya tujuan perusahaan sebab mereka dipergunakan untuk memenuhi kebutuhan perusahaan. Ketika perusahaan tidak mampu untuk menempatkan karyawan sesuai dengan kualitas dan kuantitasnya, maka mereka tidak akan menunjukkan kepuasan kerja dan pada akhirnya mereka akan memberontak dan memilih untuk keluar dari perusahaan. Oleh karena itu, penempatan karyawan yang sesuai dengan prinsip the right man in the righ place itu akan berdampak pada keefektifan dan keefisiensian karyawan dalam mencapai produktivitas kerja. Sebagaimana yang dikemukakan oleh Hasibuan (2011) menguraikan bahwa "penempatan harus didasarkan pada job description dan job specification yang telah ditentukan serta berpedoman kepada prinsip "The right man on the right place and the right man behind the job".

Produktivitas kerja karyawan akan tercapai ketika karyawan merasa dihargai dan diberikan tanggung jawab terhadap pekerjaan yang sesuai dengan keahliannya, seperti halnya teori motivasi yang dikemukakan oleh Herzberg (2009) bahwa untuk memotivasi karyawan dalam pekerjaan maka ada beberapa hal yang perlu diperhatikan untuk meningkatkan produktivitas kerja karyawan seperti halnya pengakuan, pekerjaan itu sendiri, dan tanggung jawab. Penempatan karyawan harus didasarkan pada prinsip the right man in the right place sebab apabila karyawan ditempatkan sesuai dengan tempatnya, maka karyawan akan merasa bahwa dirinya diberi tanggung jawab, dipercaya atau diakui dan mampu untuk melaksanakan pekerjaan karena memliki keahlian dan telah menunjukkan hasil kerja yang baik pada pekerjaan yang sebelumnya sehingga karyawan akan melaksanakan pekerjaan dengan luwes dan kreatif serta mampu untuk melaksanakan pekerjaan yang baru dengan lebih baik. Sudut pandang ini menggambarkan adanya kemungkinan pengaruh atau hubungan antara penempatan karyawan dengan produktivitas kerja karyawan.

Produktivitas kerja karyawan tidak hanya dipengaruhi oleh penempatan karyawan akan tetapi produktivitas kerja karyawan juga akan diperlihatkan dengan baik ketika karyawan berada pada titik 
kepuasan kerja sedangkan titik kepuasan kerja ini akan tercapai ketika harapan karyawan terpenuhi dengan adanya keadilan yang diberikan oleh pihak perusahaan. Sebagaimana yang dikemukakan oleh Sophia (2013) yang terkait dengan equity theory, bahwa "individu atau karyawan akan merasa puas bila jumlah aspek yang sebenarnya atau sesungguhnya dia terima sesuai dengan yang seharusnya dia terima". Teori ini menunjukkan bahwa ketika karyawan sudah menunjukkan hasil kerja dan layak untuk dipromosikan dan dia dipromosikan, maka karyawan yang mendapatkan promosi itu akan merasa puas. Karyawan yang merasa puas akan termotivasi untuk bekerja dengan baik sehingga karyawan akan menunjukkan hasil kerja yang baik dengan meningkatnya produktivitas kerjanya. Dengan demikian, terdapat indikasi adanya pengaruh atau hubungan antara kepuasan kerja karyawan dengan produktivitas kerja karyawan.

Memenuhi harapan dan memberikan keadilan kepada karyawan dalam perusahaan harus diaplikasikan melalui penempatan karyawan yang tepat, dimana penempatan karyawan ini berdasarkan beberapa faktor-faktor penentu dalam memberikan suatu posisi atau jabatan kepada karyawan. Ada beberapa faktor yang menjadi pertimbangan dalam menempatkan karyawan, yaitu pendidikan, pengalaman, usia, keahlian khusus, dan kualitas hasil pekerjaan. Sedangkan kepuasan kerja akan tercapai ketika karyawan merasa nyaman dengan kondisi perusahaan dan pekerjaannya. Lingkungan kerja yang baik mampu mendorong optimalisasi kinerja perusahaan. Purnamasari et al. (2020) spesialisasi tugas yang sesuai menjadi penting dalam menciptakan kualitas kerja. Jika gambaran pekerjaannya tidak jelas, karyawan tidak akan menjadi bingung dan tidak akaan menciptakan kepausan kerja. Hal yang dapat mempengaruhi kepuasan kerja karyawan dan ditentukan oleh pekerjaan itu sendiri dan kondisi kerja. Apabila penempatan yang sesuai dengan keinginan karyawan telah terwujud dan merasakan kepuasan kerja, maka hal itu akan berdampak pada produktivitas kerja karyawan. Berdasarkan pada hal tersebut, maka hipotesis dapat dirumuskan sebagai berikut:

$\mathrm{H}_{1}$ : Penempatan karyawan mempunyai pengaruh terhadap produktivitas kerja

$\mathrm{H}_{2}$ : Kepuasan kerja mempunyai pengaruh terhadap produktivitas kerja

\section{Metode Penelitian}

\section{Rancangan Penelitian dan Sampel}

Penelitian ini menggunakan analisis kuantitatif dengan metode survei dan tingkat ekplanasi asosiatif yang berbentuk hubungan kausal, maka karyawan PT. Rezki Laifasto yang menjadi sample penelitian. Sampel penelitian adalah jenuh karena hanya terdapat 71 karyawan. Pengembangan instrument penelitian didasarkan pada faktor-faktor pertimbangan penempatan karyawan seperti pendidikan, masa kerja, keahlian khsuus, kualitas hasil pekerjaan, dan usia (Siagian, 2015). Instrumen kepuasan kerja karyawan didasarkan pada pekerjaan itu sendiri, gaji, rekan sekerja, atasan, promosi, dan lingkungan kerja dan prodiktivitas kerja diuji berdasarkan indikator hasil yang dicapai, semangat kerja, pengembangan diri, mutu, kemampuan, dan efisiensi (Sutrisno, 2013).

\section{Variabel Penelitian}

Variabel dalam penelitian ini terdiri dari variabel independen dan variabel dependen. Variabel bebas (independent variable) adalah variabel yang mempengaruhi atau menjadi sebab timbulnya variabel terikat yang biasa disimbolkan sebagai variabel $X$. Dalam penelitian ini variabel bebas yang di maksud adalah penempatan karyawan (X1) dan kepuasan kerja karyawan (X2) di PT. Reski Laifasto Cabang Makassar. Sedangkan variabel terikat (dependent variable) adalah variabel yang dipengaruhi atau merupakan variabel yang menjadi akibat dari adanya variabel bebas yang biasanya disimbolkan dengan Y. Dalam penelitian ini variabel terikat yang dimaksud adalah produktivitas kerja karyawan di PT. Reski Laifasto Cabang Makassar.

Penempatan karyawan adalah pemberian jabatan atau pengisian posisi yang kosong oleh karyawan baru dan karyawan lama. Adapun indikator dalam variabel ini, sebagai berikut:

a. Pendidikan merupakan pemberian tanggung jawab jabatan kepada karyawan sesuai dengan tingak pendidikan terakhirnya.

b. Pengalaman merupakan penyesuaian antara kemampaun karyawan pada tempat kerjanya terdahulu dengan posisi atau jabatan yang akan diberikan kepadanya. 
c. Keahlian khusus merupakan keterampilan yang dimiliki oleh seorang karyawan yang tidak dimiliki oleh karyawan lain dalam menduduki suatu jabatan atau posisi yang membutuhkan keterampilan tersebut.

d. Kualitas hasil pekerjaan merupakan hasil kerja yang menunjukkan dimana karyawan mampu untuk ditempatkan kembali.

e. Usia merupakan pertimbangan untuk memberikan pekerjaan kepada karyawan yang harus disesuaikan dengan kecepatan dan ketanggapan karyawan dalam menyelesaikan pekerjaan.

Kepuasan kerja adalah perilaku positif yang diperlihatkan oleh karyawan ketika mereka menyenangi pekerjaan dan lingkungan kerjanya. Adapun indikator yang terkait dengan variabel ini, adalah:

a. Pekerjaan itu sendiri merupakan tingkat variasi yang ada dalam pekerjaan sehingga tidak menimbulkan rasa kejenuhan.

b. Gaji merupakan imbalan yang sesuai antara tingkat pekerjaan dan hasil kerja dengan kebutuhan hidup karyawan.

c. Promosi merupakan suatu hasil kerja optimal yang ditunjukkan oleh karyawan sehingga layak untuk mendapatkan tanggung jawab yang lebih tinggi.

d. Pengawasan (supervisi) merupakan gaya penilaian yang digunakan oleh supervisi dalam menyimpulkan hasil kerja.

e. Kelompok kerja merupakan kenyamanan yang didapat ketika kerjasama antara sesama rekan kerja dan atasan terjalin dengan baik.

f. Lingkungan kerja merupakan kondisi tempat kerja yang membuat karyawan merasa nyaman dan konsentrasi dalam menyelesaikan pekerjaannya.

Produktivitas kerja karyawan adalah hasil kerja yang dapat dicapai oleh karyawan berdasarkan cara yang efektif dan efesien dalam mencapai target kerja yang telah ditentukan perusahaan. Adapun indikator pada variabel ini, yaitu:

a. Hasil yang dicapai merupakan kemauan karyawan dalam bekerja untuk terus berusaha mencapai hasil kerja yang maksimal.

b. Semangat kerja merupakan keinginan peningkatan hasil kerja yang harus lebih baik dari hari kemarin bersarkan penghargaan yang diberikan oleh rekan kerja dan pimpinan perusahaan.

c. Pengembangan diri merupakan kemampuan kerja untuk menghadapi tantangan dan harapan dengan apa yang akan dihadapi.

d. Mutu merupakan hasil pekerjaan yang dapat menunjukkan kualitas kerja seorang karyawan.

e. Kemampuan adalah keterampilan yang dimiliki oleh karyawan dalam menyelesaikan pekerjaan.

f. Efesiensi merupakan kemampuan karyawan mengelola pekerjaan dengan menggunakan sumber daya yang ada.

\section{Teknik Analisis Data}

Analisis regresi linear berganda merupakan hubungan secara linear antara dua atau lebih variabel independen $\left(\mathrm{X}_{1}, \mathrm{X}_{2}, \ldots \mathrm{Xn}\right)$ dengan variabel dependen $(\mathrm{Y})$. Analisis ini digunakan untuk mengetahui arah hubungan antara variabel independen dengan variabel dependen, dan apakah masing - masing variabel independen berhubungan positif atau negatif serta untuk memprediksi nilai dari variabel dependen apabila nilai vaiabel independen mengalami kenaikan atau penurunan (Sugiyono, 2010). Adapun rumus persamaan regresi linear berganda yang digunakan yaitu:

Dimana:

$$
Y^{\prime}=a+b_{1} x_{1}+b_{2} x_{2}+\varepsilon
$$

\footnotetext{
Y= Produktivitas Kerja

$\mathrm{X} 1=$ Penempatan Kerja

$\mathrm{X} 2=$ Kepuasan Kerja
} 


\section{Hasil dan Pembahasan}

\section{Hasil Penelitian}

Hasil penelitian menyajikan koefisien determinasi serta efek signifikansi pada hubungan produktivitas kerja dan kepuasan kerja karyawan terhadap produktivitas kerja.

Tabel 1. Koefisien Determinasi R Square

\begin{tabular}{ccccc}
\hline Model & $\mathrm{R}$ & R Square & $\begin{array}{c}\text { Adjusted } \mathrm{R} \\
\text { Square }\end{array}$ & $\begin{array}{c}\text { Std. Error of the } \\
\text { Estimate }\end{array}$ \\
\hline 1 &, $845^{\mathrm{a}}$ & 0,714 & 0,706 & 2,241 \\
\hline
\end{tabular}

Pada Tabel 1, hasil koefisien determinas R Square 0,714 dengan Adjusted R Square 0,706. Hasil ini mengindikasikan bahwa kontribusi variabel bebas terhadap variabel terikat sebesar 0,714 atau $71,4 \%$ sedangkan sisanya sebesar $28,60 \%$ dipengaruhi atau dijelaskan oleh variabel lain yang tidak dimasukkan dalam model penelitian ini. Nilai $\mathrm{R}^{2}$ terkoreksi sebesar 0,706 . Nilai ini menunjukkan bahwa variabel penempatan karyawan dan kepuasan kerja karyawan secara bersama - sama dapat menjelaskan 70,6\% variasi variabel produktivitas kerja karyawan.

Setelah pengaruh variabel dependen terhadap variabel independen diketahui, maka selanjutnya dilakukan pengujian regresi linear ganda dengan tujuan untuk mengetahui kualitas produktivitas kerja karyawan apabila penempatan karyawan dan kepuasan kerja karyawan ditingkatkan sampai nilai optimal, namun terlebih dahulu akan disajikan persamaan regresi linear ganda dari nilai hasil olah data penelitian seperti pada tabel 2 berikut.

Tabel 2 Hasil Uji Efek Signifikansi

\begin{tabular}{lccc}
\hline \multicolumn{1}{c}{ Variabel } & Konstanta & $\mathrm{t}$ & Sig. \\
\hline Konstan & 18,656 & 4,205 & 0,000 \\
Penempatan Karyawan (X1) & 0,093 & 2,134 & 0,036 \\
Kepuasan Kerja Karyawan (X2) & 0,624 & 11,889 & 0,000 \\
\hline
\end{tabular}

Persamaan regresi memberikan pengertian bahwa apabila nilai koefesien variabel $\mathrm{X}_{1}$ (penempatan karyawan) ditingkatkan sebesar satu satuan maka akan menyebabkan peningkatan nilai dari variabel Y (produktivitas kerja karyawan) sebesar 0,093 satuan dan begitupula dengan koefesien variabel $\mathrm{X}_{2}$ (kepuasan kerja karyawan) apabila ditingkatkan sebesar satu satuan maka akan menyebabkan peningkatan nilai dari variabel $\mathrm{Y}$ sebesar 0,624 sedangkan nilai konstanta 18,656 memberikan pengertian bahwa apabila tidak ada pengaruh dari variabel $\mathrm{X}_{1}$ dan $\mathrm{X}_{2}$, maka nilai dari variabel $\mathrm{Y}$ akan tetap berada pada nominal 18,656.

Secara keseluruhan, penelitian ini menunjukkan pengaruh yang signifikan pada level di bawah 5\%. Pada rumusan hipotesis, H1 diterima yang menyatakan bahwa penempatan karyawan mempunyai pengaruh terhadap produktivitas kerja dan $\mathbf{H 2}$ diterima bahwa kepuasan kerja mempunyai pengaruh terhadap produktivitas kerja.

Hasil uji hipotesis $\mathrm{H} 1$ dan $\mathrm{H} 2$ diterima yang menyatakan bahwa penempatan karyawan dan kepuasan kerja mempunyai pengaruh terhadap produktivitas kerja pada PT. Reski Laifasto Cabang Makassar. Oleh karena itu, pengujian hipotesis menunjukkan bahwa terjadi pengaruh antara penempatan karyawan dan kepuasan kerja karyawan terhadap produktivitas kerja karyawan.

\section{Pengaruh Penempatan Karyawan terhadap Produktivitas Kerja Karyawan}

Produktivitas pekerjaan karyawan dapat dipengaruhi oleh siapa yang melaksanakan pekerjaan itu dan bagaimana cara karyawan menyelesaikan pekerjaan. Penentuan berhasil tidaknya pekerjaan terselesaikan dengan baik sangat tergantung pada orang yang ditempatkan untuk melaksanakan pekerjaan sehingga ada beberapa indikator yang perlu untuk diperhatikan sekaitan dengan 
penempatan karyawan dan indikator tersebut umumnya harus diterapkan untuk bisa mendapatkan produktivitas yang baik. Ada 5 indikator yang dipergunakan dalam penelitian ini untuk melihat pengaruhnya terhadap produktivitas kerja karyawan dan hasil analasis penelitian menunjukkan bahwa indikator pengalaman dan kualitas hasil kerja berada pada kategori tidak signifikan.

Hasil analisis memberikan gambaran bahwa masih ada beberapa indikator atau faktor yang harus lebih diperhatikan pengaruhnya terhadap produktivitas kerja karyawan terutama indikator pengalaman kerja karyawan yang akan memberikan pengaruh terhadap produktivitas kerja karyawan dengan cara meperhatikan dan menerapkan job description dan job specifikation dalam menempatkan karyawan. Seperti halnya yang dikemukakan oleh Hasibuan (2011) bahwa penerapan the right man in the right place harus didukung oleh analisis job description dan job specifikation. Hal ini dikarenakan apabila orang yang ditempatkan pada suatu bidang pekerjaan tidak sesuai dengan spesifikasi keahliannya maka mereka akan kesulitan dalam menyelesaikan pekerjaan dan tidak mampu untuk mengembangkan kemampuan dan keahliannya dalam bekerja karena salah satu motivasi seorang karyawan untuk mau bekerja dengan baik adalah ketika mereka menyenangi pekerjaannya seperti halnya teori motivasi higienis dari herzberg dalam (Pearce \& Robinson, 2009) yang mengindikasikan bahwa penempatan karyawan berpengaruh terhadap produktivitas kerja karyawan dan salah satu bentuk motivasi yang berkaitan dengan penempatan karyawan dalam mempengaruhi produktivitas kerja karyawan adalah tantangan dalam pekerjaan (Fallis et al., 2014).

Hasil temuan penelitian juga sejalan dengan temuan penelitian terdahulu (Atmajati \& Mansur, 2017; Din \& Sumarauw, 2018; Pratiwi, 2013) yang menemukan bahwa penempatan tenaga kerja berpengaruh secara signifikan terhadap produktivitas kerja karyawan dengan indikator prestasi akademis, pengalaman, dan kesehatan fisik dan mental.

\section{Pengaruh Kepuasan Kerja Karyawan terhadap Produktivitas Kerja Karyawan pada PT. Reski Laifasto Cabang Makassar}

Hasil uji analisis regresi ganda menunjukkan bahwa kepuasan kerja karyawan (X2) berpengaruh secara signifikan terhadap produktivitas kerja karyawan. Hasil penelitian ini demikian menunjukkan bahwa tinggi rendahnya produktivitas kerja karyawan pada PT. Reski Laifasto Cabang Makassar dipengaruhi oleh kepuasan kerja karyawan.

Indikator kepuasan kerja yang paling dominan dapat mempengaruhi produktivitas kerja karyawan berdasarkan nilai beta pada analisis regresi linear ganda adalah gaji. Gaji merupakan suatu bentuk penghargaan yang diberikan oleh perusahaan berdasarkan hasil kerja karyawan. Apabila karyawan telah menyelesaikan pekerjaan dengan baik namun tidak sesuai antara beban kerja dengan imbalan yang diberikan oleh perusahaan serta tidak sesuainya besar imbalan antara anggota kelompok kerja dengan beban kerja yang sama dapat membuat karyawan merasa tidak puas dan menimbulkan suatu bentuk protes ke perusahaan dengan memperlihatkan suatu ketidak disiplinan dalam bekerja seperti tidak tepat waktu masuk kerja dan sering mangkir atau tidak tepat waktu menyelesaikan pekerjaan. Ketidak adilan pihak perusahaan dalam menunjang produktivitas kerja karyawan juga ditentukan oleh adil atau tidaknya karyawan dalam memberikan promosi jabatan kepada karyawan lama jangan sampai hanya karena adanya hubungan kedekatan tanpa memperhatikan kualitas hasil kerja yang menjadi salah satu pertimbangan dalam memberikan promosi.

Besarnya gaji bukanlah suatu indikator mutlak yang dapat menentukan kepuasan kerja karyawan karena meskipun karyawan mendapatkan gaji yang sudah melebihi kebutuhan hidup dan sesuai antara hasil kerja dengan imbalan yang diberikan oleh perusahaan akan tetapi ketika tidak ada kerja sama yang baik antara anggota kelompok kerja akab mengakibatkan karyawan tidak nyaman dalam berkerja sehingga dampaknya produktivitas kerja karyawan akan menurun. Salah satu semengat karyawan dalam bekerja adalah motivasi dari anggota kelompok dan saling berbagi apabila mengalami kesulitan dalam berkerja demi untuk mendapatkan solusi terhadap permasalahan yang dihadapi.

Karyawan pada PT. Reski Laifasto Cabang Makassar sebagian besar kepuasan kerjanya belum sampai pada tittik yang maksimal karena adanya perbedaan imbalan yang diberikan kepada tiga golongan karyawan. Apabila karyawan masih dalam golongan karyawan baru (magang), maka mereka akan mendapatkan imbalan dibawah UMP (Upah Minimum Provinsi) sedangkan untuk karyawan kontrak dan magang mereka diberikan imbalan sesuai dengan UMP. Sehingga akan terjadi 
perbedaan semangat dalam bekerja yang berdampak pada produktiv atau tidaknya karyawan dalam bekerja.

Puas atau tidak puasnya karyawan dalam bekerja tergantung dari rasa nyaman dan adil atau tidaknya perusahaan dalam memberikan imbalan kepada karyawan, seperti halnya dengan equity theory yang dikemukakan oleh Sopiah (2013) yang menyatakan bahwa kepuasan kerja akan dirasakan oleh karyawan ketika mereka diperlakukan adil oleh perusahaan yang berdampak kepada produktivitas atau tidaknya karyawan dalam bekerja sehingga mengindikasikan bahwa ada pengaruh yang signifikan antara kepuasan kerja karyawan terhadap produktivitas kerja karyawan. Temuan hasil penelitian sejalan dengan temuan terdahulu (Novita et al., 2016; Sabena et al., 2016) bahwa kepuasan kerja berpengaruh secara signifikan terhadap produktivitas kerja karyawan dengan indikator pertanggungjawaban, peningkatan kerja, dan kemajuan.

\section{Kesimpulan}

Penempatan karyawan dan kepuasan kerja karyawan berpengaruh positif terhadap produktivitas kerja karyawan pada PT. Reski Laifasto Cabang Makassar. Peningkatan produktivitas kerja dipengaruhi oleh kesesuaian penempatan kerja dan kepuasan karyawannya. Penempatan karyawan berpengaruh terhadap produktivitas kerja karyawan, maka disarankan kepada pihak perusahaan untuk lebih memperhatikan latar belakang penidikan, pengalaman dan kualitas hasil pekerjaan karyawan dalam menempatkan karyawan sebagai dasar pertimbangan untuk mencapai produktivitas kerja karyawan yang lebih baik. Di samping itu, pihak perusahaan untuk bisa memperhatikan kerjasama antara kelompok kerja dan kondisi lingkungan kerja. Kepuasan kerja karyawan harus diperhatikan sepenuhnya oleh perusahaan karena produktivitas kerja karyawan akan meningkat ketika karyawan merasa nyaman dan senang dalam melaksanakan pekerjaan.

\section{Daftar Pustaka}

Atmajati, A. R., \& Mansur. (2017). Pengaruh Rekrutmen, Seleksi, dan Penempatan Tenaga Kerja Terhadap Produktivitas Kerja Karyawan Pada PT. Bank Papua Jayapura. Jurnal Manajemen Dan Akuntansi.

Din, S. T. N., \& Sumarauw, J. S. B. (2018). Pengaruh Rekrutmen, Seleksi, dan Penempatan Kerja terhadap Produktivitas Kerja di PT. HM. Sampoerna Tbk. Jurnal EMBA.

Fallis, A. ., Robbins, S. P., \& Judge, T. (2014). Organizational Behaviour, Global Edition. In Journal of Chemical Information and Modeling. https://doi.org/10.1017/CBO9781107415324.004

Fandi, A. (2016). Concept and Indicator Human Resources Management for Management Research. 1st Ed Yogyakarta.

Firana, Y., \& Abbas, A. (2020). Dimensi Keadilan dalam Partisipasi Penyusunan Anggaran dan Kinerja Manajerial Rumah Sakit. Jesya (Jurnal Ekonomi \& Ekonomi Syariah). https://doi.org/10.36778/jesya.v3i2.150

Handoko, T. H. (2011). Manajemen Personalia dan Sumber Daya Manusia. Pengantar Manajemen.

Hasibuan, M. S. P. (2011). Manajemen Sumber Daya Manusia. Edisi Revisi Jakarta: Bumi Aksara.

Herzberg, F. (2009). Frederick Herzberg The hygiene Motivation theory. Chartered Management Institute.

Luthans. (2012). Komitmen Organisasi. Prilaku Organisasi.

Luthans, F. (2002). Positive organizational behavior: Developing and managing psychological strengths. Academy of Management Executive. https://doi.org/10.5465/AME.2002.6640181

Mangkunegara. (2011). Manajemen Sumber Daya Perusahaan. In Manajemen Sumber Daya Perusahaan.

Mathis, L. R., \& Jackson, H. J. (2019). Human Resource Management: Personnel Human Resource Management. Harvard Business Review.

Novita, N., Sunuharjo, B., \& Ruhana, I. (2016). PENGARUH KEPUASAN KERJA DAN KOMITMEN ORGANISASIONAL TERHADAP KINERJA KARYAWAN (Studi pada PT. Telekomunikasi Indonesia, Tbk Witel Jatim Selatan, Malang). Jurnal Administrasi Bisnis S1 Universitas Brawijaya.

Pearce, J. A., \& Robinson, R. B. (2009). Manajemen Strategis: Formulasi, Implementasi, dan Pengendalian. In Jakarta: Salemba Empat. 
Pratiwi, V. (2013). Pengaruh spesifikasi jabatan terhadap penempatan pegawai pada kpp pratama pematangsiantar. Jurnal Manajemen Keuangan.

Purnamasari, R., Abbas, A., \& Firana, Y. (2020). Analyzing The Company's Work Environment Within the Task Complexity. Almana: Jurnal Manajemen dan Bisnis, 4(2), 230-236.

Sabena, A., Hamdani Harahap, R., \& Tarigan, U. (2016). Pengaruh Motivasi Kerja dan Kepuasan Kerja terhadap Peningkatan Produktivitas Kerja Karyawan. Jurnal Administrasi Publik: Public Administration Journal. https://doi.org/10.31289/jap.v6i2.1329

Sedarmayanti. (2016). Manajemen Sumber Daya Manusia. In Manajemen Sumber Daya Manusia.

Siagian, S. P. (2015). Manajemen Sumber Daya Manusia. In Jakarta : Bumi Aksara.

Sopiah, S. (2013). The Effect of Compensation toward Job Satisfaction and Job Performance of Outsourcing Employees of Syariah Banks in Malang Indonesai. International Journal of Learning and Development. https://doi.org/10.5296/ijld.v3i2.3612

Sugiyono. (2010). Metode Penelitian Bisnis. Pendekatan Kuantitatif, kualitatif dan R \& D. Bandung: Alfabeta.

Sunyoto, D. (2013). Manajemen Sumber Daya Manusia. Yogyakarta: CAPS (Center Of Academic Publishing Service).

Sutrisno. (2013). Manajemen Keuangan Teori Konsep dan Aplikasi. In Manajemen Keuangan Teori Konsep dan Aplikasi.

\section{*Email korespondensi:}

Nurleli Ramli

nurleliramli@iainpare.ac.id 